\title{
EXSOLUTION TEXTURES IN HIGH PRESSURE GARNETS, MIR KIMBERLITE, SIBERIA
}

\author{
Michael Roden ${ }^{\mathrm{a}}$, Alberto Patino-Douce ${ }^{\mathrm{a}}$, Evgenii Laz'ko ${ }^{\mathrm{a}}$, Emil Jagoutz ${ }^{\mathrm{b}}$ \\ ${ }^{a}$ Dept. of Geology, University of Georgia, Athens GA, USA; ${ }^{b}$ Max Planck Institut Chemie, Mainz, Germany
}

One of the more intriguing findings of the last 15 years or so is the recognition of very high pressure rocks and minerals. These occurrences include: ultrahigh-pressure metamorphic terranes containing minerals (e.g., diamond, coesite) indicative of pressures higher than 30 kbar (e.g., Smith, 1984; Sobolev and Shatsky, 1990; Wain, 1997) (2) very high pressure mineral inclusions (e.g., majoritic garnet, ferropericlase) in diamonds from kimberlites (e.g., Tsai et al., 1979; Moore and Gurney, 1985; Stachel et al., 2000), and (3) exsolved phases in host minerals that suggest that the original mineral had a composition indicative of very high pressures (Haggerty and Sautter, 1990; Zhang and Liou, 1999).

Proposed examples of exsolution due to decompression (\#3 above) from very high pressure include rods of ilmenite in olivines from the Alpe Arami garnet peridotite massif (Dobrzhinetskaya et al., 1996) and the Dabie-Sulu ultra high pressure terrane (Hacker et al., 1997), K-feldspar lamellae in clinopyroxene and coesite in titanite from diamondbearing rocks of the ultrahigh-pressure Kokchetav massif, Kazakhstan (Sobolev and Shatsky, 1990; Ogasawa et al., 2002), K-feldspar lamellae in clinopyroxene inclusions in eclogitic garnets from kimberlites (Harlow and Veblen, 1991) and rods of pyroxene in garnet from kimberlite xenoliths (Haggerty and Sautter, 1990) and orogenic garnet peridotites from the Western Gneiss region of Norway (van Roermund and Drury, 1998).

Some elemental substitutions in garnet are also thought to be indicative of high pressure, and to result in exsolution of various minerals if the garnet reequilibrates at low pressures. Experimental evidence is most clear for the incorporation of supersilicic, majoritic components $\left(\mathrm{MSiAl}_{-2}\right.$ where $\mathrm{M}$ $\left.=\mathrm{Fe}^{2+}, \mathrm{Mg}, \mathrm{Ca}\right)$ in garnets at pressures greater than 50 kbar (e.g., Akaogi and Akimoto, 1979; Irifune 1987; Gasparik, 1989). A second important mechanism for producing supersilicic garnets at high pressure is via a $\mathrm{NaSi}(\mathrm{MgAl})_{-1}$ substitution (Gasparik, 1989). Hence, excess $\mathrm{Si}$ in the octahedral site of garnet appears to be an ultrahigh-pressure signature. If a majoritic garnet reequilibrates in the lithosphere, the supersilicic component exsolves as pyroxene (e.g., Haggerty and Sautter, 1990; van Roermund and Drury, 1998). Thus, for mantle-derived garnets in which pyroxene (i.e., the majoritic component) alone has exsolved, the experimental evidence supports an ultrahigh-pressure origin for the original garnet because the exsolved pyroxene contains Si that was formerly in octahedral coordination in the garnet (e.g., Gasparik, 1989).

There are other elemental substitutions (Ti, P, $\mathrm{Na}$ without excess $\mathrm{Si}$ ) which may also be indicative of very high pressures (e.g., Ringwood and Lovering, 1970; Sobolev and Lavrent'ev, 1971; Bishop et al., 1976; Reid et al., 1976). Na-, Ti- and P- rich garnets are evidenced by relatively high abundances of these elements in homogeneous garnets or exsolved phases such as rutile, ilmenite, clinopyroxene, and apatite which contain appreciable amounts of these constituents (Fig. 1). For example, garnets equilibrated (both in nature and in experiments) at moderate to high pressures and temperatures are known to contain up to $2.5 \mathrm{wt} \% \mathrm{TiO}_{2}, 1.6 \mathrm{wt} \% \mathrm{Na}_{2} \mathrm{O}$ and $0.6 \mathrm{wt} \% \mathrm{P}_{2} \mathrm{O}_{5}$ (e.g., Sobolev \& Lavrentyev, 1971; Thompson, 1975; Reid et al., 1976; Bishop et al., 1976, 1978; Moore and Gurney, 1985; Haggerty et al., 1994; Ono, 1998; Mproskos and Kostopoulos, 2001). Other garnets have exsolved rutile, Na-bearing diopside and apatite indicating that the initial garnet had appreciable amounts of $\mathrm{Ti}, \mathrm{Na}$ and/or P (e.g., Haggerty, 1996; Roden et al., 1999; Ye et al., 2000; Mproskos and Kostopoulos, 2001). Due to the exsolution of Si-poor rutile or apatite, the original garnets may not have been supersilicic.

Some garnets from high-Mg garnet pyroxenite xenoliths from Mir have triangular arrays of mineral inclusions consistent with an origin by exsolution (Fig. 1). The inclusions are small $(\sim 100$ micrometers), controlled by the garnet structure, and concentrated in the centers of grains. We have identified 6 high $\mathrm{Mg}$ garnet clinopyroxenites and websterites that contain garnet that is rich in these inclusions. The mineral assemblages contained in the garnets are variable, and consist of: diopside + rutile, diopside alone, rutile + high $\mathrm{Mg}$ (13-17 wt.\% $\mathrm{MgO}$ ) ilmenite and high $\mathrm{Mg}$ ilmenite alone (Table 1). Somewhat similar assemblages have been reported in garnets from the Jagersfontein kimberlite and in garnets of Norwegian orogenic peridotites (Haggerty and Sautter, 1990; Van Roermund et al., 2000). Exsolution of diopside by itself indicates that the garnet was supersilicic and formed at very high pressures. The other exsolved mineral assemblages do not require an originally supersilicic garnet, and experimental evidence is lacking to 
constrain the pressure and temperature of origin. Exsolution of diopside and rutile could result from coupled substitution of $\mathrm{Na}$ and $\mathrm{Ti}$ in garnet and exsolution of ilmenite may reflect an Al- and Si- poor garnet component. These substitutions may represent high temperature rather than high pressure substitutions if the pyroxenites formed as cumulates from an alkaline, magnesian magma intrusive into the lithosphere. Thermobarometric calculations (Brey and Kohler, 1990) for two of these pyroxenites show that they last equilibrated in the lithosphere at relatively low temperatures $\left(750-800^{\circ} \mathrm{C}\right)$ and moderate pressures (20-30 kb, Roden et al., 1999).

Table 1: Representative Mineral Analyses

\begin{tabular}{|c|c|c|c|c|c|c|}
\hline $\begin{array}{l}\text { Sample } \\
\text { Mineral }\end{array}$ & $\begin{array}{l}\text { TM-90 } \\
\text { discrete } \\
\text { enstatite }^{*}\end{array}$ & $\begin{array}{l}\text { TM-126 } \\
\text { discrete } \\
\text { enstatite }\end{array}$ & $\begin{array}{l}\text { TM-149 } \\
\text { discrete } \\
\text { enstatite }^{*}\end{array}$ & $\begin{array}{l}\text { TM-90 } \\
\text { host } \\
\text { garnet* }^{*}\end{array}$ & $\begin{array}{l}\text { TM-126 } \\
\text { host } \\
\text { garnet }\end{array}$ & $\begin{array}{l}\text { TM-149 } \\
\text { host } \\
\text { garnet }^{*}\end{array}$ \\
\hline $\mathrm{SiO}_{2}$ & 58.40 & 58.14 & 57.23 & 42.87 & 41.76 & 42.17 \\
\hline $\mathrm{TiO}_{2}$ & 0.07 & 0.03 & 0.05 & 0.09 & 0.07 & 0.17 \\
\hline $\mathrm{Al}_{2} \mathrm{O}_{3}$ & 0.62 & 0.54 & 1.09 & 23.52 & 23.05 & 22.72 \\
\hline $\mathrm{MgO}$ & 37.31 & 36.20 & 36.07 & 21.67 & 21.22 & 20.43 \\
\hline $\mathrm{FeO}$ & 3.71 & 4.80 & 4.48 & 6.77 & 7.35 & 8.08 \\
\hline $\mathrm{CaO}$ & 0.17 & 0.20 & 0.11 & 4.43 & 5.06 & 4.4 \\
\hline $\mathrm{MnO}$ & 0.06 & 0.16 & 0.06 & 0.18 & 0.39 & 0.26 \\
\hline $\mathrm{Na}_{2} \mathrm{O}$ & nd & 0.05 & nd & na & & na \\
\hline $\mathrm{Cr}_{2} \mathrm{O}_{3}$ & 0.09 & 0.19 & 0.2 & 0.91 & 1.77 & 1.19 \\
\hline Total & 100.43 & 100.31 & 99.29 & 100.44 & 100.67 & 99.42 \\
\hline Mg\# & 94.7 & 93.1 & 93.5 & & & \\
\hline mol\% pyr & & & & 75.4 & 72.7 & 72.3 \\
\hline
\end{tabular}

\begin{tabular}{llllll} 
Sample & TM-90 & TM-90 & TM-149 & TM-149 & TM-126 \\
Mineral & diopside & rutile & rutile & ilmenite & diopside \\
& inclusion & inclusion & inclusion & inclusion & inclusion \\
\hline
\end{tabular}

\begin{tabular}{lrrrrr}
$\mathrm{SiO}_{2}$ & 54.76 & 0.07 & 0.18 & 0.11 & 55.09 \\
$\mathrm{TiO}_{2}$ & 0.21 & 97.07 & 97.98 & 58.61 & nd \\
$\mathrm{Al}_{2} \mathrm{O}_{3}$ & 2.51 & 0.2 & 0.07 & 0.17 & 1.89 \\
$\mathrm{MgO}$ & 17.14 & nd & 0.02 & 16.78 & 17.18 \\
$\mathrm{FeO}$ & 1.09 & 0.49 & 0.61 & 23.58 & 1.58 \\
$\mathrm{CaO}$ & 22.15 & 0.19 & 0.22 & 0.18 & 22.93 \\
$\mathrm{MnO}$ & $\mathrm{nd}$ & $\mathrm{nd}$ & 0.01 & 0.23 & 0.14 \\
$\mathrm{Na}_{2} \mathrm{O}$ & 1.68 & $\mathrm{na}$ & na & na & 1.36 \\
$\mathrm{Cr}_{2} \mathrm{O}_{3}$ & 0.64 & 1.23 & 0.93 & 0.66 & 0.81 \\
$\mathrm{Total}$ & 100.18 & 99.25 & 100.02 & 100.31 & 100.97 \\
$\mathrm{Mg \#}$ & & & & & \\
\hline
\end{tabular}

Notes: TM-90 garnets have rutile \& diopside inclusions; TM-149 garnets have rutile and ilmenite inclusions, TM-126 garnets have diopside inclusions. *from Roden et al., 1999 

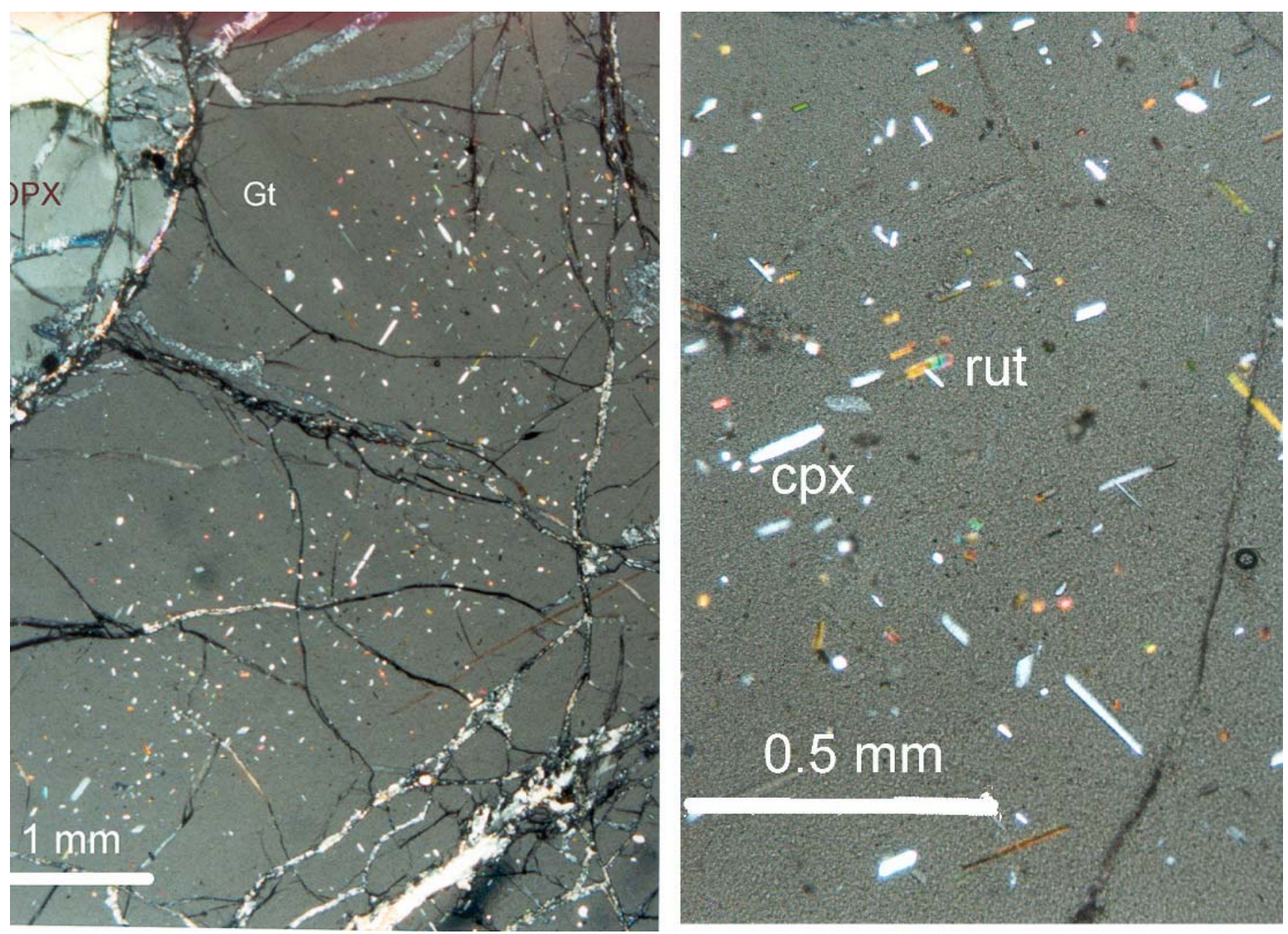

Figure 1. Diopside and rutile inclusions in garnet, garnetite TM-90.

\section{REFERENCES}

Akaogi, M., Akimoto, S., 1979. High pressure phase equilibria in a garnet lherzolite, with special reference to $\mathrm{Mg}^{2+}-\mathrm{Fe}^{2+}$ partitioning among constituent minerals, Phys. Earth Planet Int. 19, 3151 .

Bishop, F.C., Smith, J.V., Dawson, J.B., 1976. Na, P, Ti and coordination of $\mathrm{Si}$ in garnet from peridotite and eclogite xenoliths. Nature 260, 696-697.

Bishop, F.C., Smith, J.V., Dawson, J.B., 1978. Na, K, P and $\mathrm{Ti}$ in garnet, pyroxene and olivine from peridotite and eclogite xenoliths from African kimberlites. Lithos 11, 155-173.

Brey, G., Kohler, T., 1990. Geothermobarometry in fourphase lherzolites II. New thermobarometers and practical assessment of existing thermobarometers, J. Petrol. 31. 1353-1378.

Dobrzhinetskaya, L., Green, H.W. II, Wang, S., 1996. Alpe Arami: A peridotite massif from depths of more than 300 kilometers. Science 271, 1841-1845.

Gasparik, T., 1989. Transformation of enstatite - diopside jadeite pyroxenes to garnet. Contr. Mineral. Petrol. 102, 389-405.

Hacker, B.R., Sharp, T., Zhang, R.Y., Liou, J.G., Hervig, R.L., 1997. Determining the origin of ultrahighpressure lherzolites. Science 278, 702-704

Haggerty, S.E., 1996. Petrochemistry of ultradeep ( $>300$ $\mathrm{km})$ and transition zone xenoliths [abstract]. Extended Abstracts, $6^{\text {th }}$ Int. Kimberlite Conf. Novosibirsk, Russia, pp. 214-215.

Haggerty, S.E., Sautter, V., 1990. Ultradeep (greater than 300 kilometers), ultramafic upper mantle xenoliths. Science 248, 993-996. 
Haggerty, S.E., Fung, A.T., Burt, D.M., 1994. Apatite, phosphorus and titanium in eclogitic garnet from the upper mantle. Geophys. Res. Letters 21, 1699-1702.

Harlow, G.E., Veblen, 1991. Potassium in clinopyroxene inclusion from diamonds. Science 251, 652-655.

Irifune, T., 1987. An experimental investigation of the pyroxene-garnet transformation in a pyrolite composition and its bearing on the constitution of the mantle. Phys. Earth Planet. Int. 45, 324-336.

Moore, R.O., Gurney, J.J., 1985. Pyroxene solid solution in garnets included in diamond. Nature 318, 553-555.

Mposkos, E.D., Kostopoulos, D.K., 2001. Diamond, former coesite and supersilicic garnet in metasedimentary rocks from the Greeek Rhodope: a new ultrahighpressure metamorphic province estlbished. Earth Planet. Sci. Lett. 192, 497-506.

Ogasawa, Y., Fukasawa, K.,Maruyama, S., 2002. Coesite exsolution from supersilicic titanite in UHP marble from the Kokchetav Massif, northern Kazakhstan. Am. Min. 87, 454-461.

Ono, S., 1998. Stability limits of hydrous minerals in sediment and mid-ocean ridge basalt compositions: Implications for water transport in subduction zones. J. Geophys. Res. 103, 18,253-18,267.

Reid, A.M., Brown, R.W., Dawson, J.B., Whitfield, G.G., Siebert, J.C., 1976. Garnet and pyroxene compositions in some diamondiferous eclogites. Contrib. Mineral. Petrol. 58, 203-220.

Roden, M.F., Laz'ko, E.E., Jagoutz, E., 1999. The role of garnet pyroxenites in the Siberian lithosphere: Evidence from the Mir kimberlite. In Gurney, J.J., Gurney, J.L., Pascoe, M.D., Richardson, S.H. (Eds.), Proceedings of the VIIth International Kimberlite Conference, Red Roof Design cc, Cape Town, pp. 714-720.

Smith, D.C., 1984. Coesite in clinopyroxene in the Caledonides and its implications for geodynamics. Nature 310, 641-644.

Sobolev, N.V., Lavrent'ev, J.G., 1971. Isomorphic sodium admixture in garnets formed at high pressure. Contrib. Mineral. Petrol. 31, 1-12.
Sobolev, N., Shatsky, V., 1990. Diamond inclusions in garnets from metamorphic rocks. Nature 343, 742 746.

Stachel, T., Harris, J.W., Brey, G.P., Joswig, W., 2000. Kankan diamonds (Guinea) II: lower mantle inclusion parageneses, Contr. Mineral. Petrol. 140, $16-27$.

Thompson, R.N., 1975. Is upper-mantle phosphorus contained in sodic garnet? Earth Pl. Sci. Letters 26, 417-424.

Tsai, H., Meyer, H.O.A., Moreau, J., Milledge, H.J., 1979. Mineral inclusions in diamond: Premier, Jagersfontein, and Finsch kimberlites, South Africa, and Williamston mine, Tanzania. In Boyd, F.R., Meyer, H.O.A. (Eds.) Kimberlites, Diatremes and Diamonds: Their Geology Petrology and Geochemistry, Am. Geophys. U., Washington, pp. 16-26.

van Roermund, H.L.M., Drury, M.R. 1998. Ultra-high pressure $(\mathrm{P}>6 \mathrm{Gpa})$ garnet peridotites in western Norway: exhumation of mantle rocks from $>185 \mathrm{~km}$ depth. Terra Nova 10, 295-301.

Van Roermund, H.L.M., Drury, M.R., Barnhoorn, A., De Ronde, A., 2000, Non-silicate inclusions in garnet from an ultra-deep orogenic peridotite. Geol. J. 35, 209-229.

Wain, A., 1997. New evidence for coesite in eclogite and gneisses: Defining an ultrahigh-pressure province in the Western Gneiss region of Norway. Geology 25, 927-930.

Ye, K., Cong, B. Ye, D., 2000. The possible subduction of continental material to depths greater than $200 \mathrm{~km}$. Nature 407, 734-736.

Zhang, R.Y., Liou, J.G., 1999. Exsolution lamellae in minerals from ultrahigh-pressure rocks. International Geology Review, 41, 981-993.

Contact: M. Roden, Dept Geology, University of Georgia, Athens GA 30602, E-mail: mroden@gly.uga.edu 